\title{
PELATIHAN PEMBUATAN VIDEO PEMBELAJARAN PADA GURU TK NEGERI KINTAMANI, BALI
}

\author{
Elizabeth Prima ${ }^{1}$, Christiani Endah Poerwati ${ }^{2}$, Putu Indah Lestari ${ }^{3}$, I Made Elia Cahaya ${ }^{4}$, \\ Ni Made Ayu Suryaningsih ${ }^{5}$, Ni Luh Rimpiati ${ }^{6}$ \\ 1,2,3,4,5,6 Universitas Dhyana Pura, Indonesia
}

Email: elizabethprima@undhirabali.ac.id

\begin{abstract}
Abstrak
Pandemi Covid-19 membuat proses belajar mengajar tidak dapat berjalan dengan semestinya. Aktivitas yang melibatkan banyak orang tidak dilaksanakan guna mencegah penyebaran virus Covid-19. Hal ini berdampak kepada proses belajar mengajar di TK Negeri Kintamani yang berlokasi di Jalan Raya Kintamani, Desa Kintamani Kecamatan Kintamani Kabupaten Bangli, Provinsi Bali. Selama belajar dari rumah (BDR) guru mengalami kesulitan dalam memberikan materi pembelajaran. Guru hanya mampu mengirim tugas yang akan dikerjakan oleh anak-anak melalui aplikasi whatsapp group tanpa dilengkapi video pembelajaran yang dapat di terima dan pelajari anak dirumah. Kurangnya pengetahuan guru akan cara pembuatan pembelajaran dalam format video pembelajaran menjadi dasar pemikiran mengapa PKM Prodi ini dilakuan. Subjek dari PKM ini adalah guru-guru di TK Negeri Kintamani. Metode yang digunakan dalam PKM ini adalah pendampingan pembuatan video pembelajaran yang dilaksanakan dengan menerapkan protokol kesehatan. Tujuan dari PKM Prodi ini adalah untuk melatih dan mendampingi guru-guru TK dalam membuat video pembelajaran mulai dari proses pengambilan gambar, editing, hingga unggah di kanal YouTube sekolah agar dapat di share dan dipelajari oleh siswa. Hasil dari evaluasi kegiatan pelatihan dan pendampingan ini adalah guru-guru mampu membuat video pembelajaran dan mengunggahnya di kanal YouTube sekolah. Dengan demikian, guru tidak lagi terkendala saat pelaksanaan proses belajar mengajar meskipun siswa belajar dari rumah (BDR).
\end{abstract}

Kata Kunci : pelatihan, video pembelajaran, taman kanak-kanak

\section{PENDAHULUAN}

Pandemi Covid-19 mempengaruhi berbagai sektor kehidupan, termasuk pendidikan. Hal ini memberikan tantangan baru, terutama bagi para pendidik yang harus melaksanakan pembelajaran jarak jauh/daring atau Belajar Dari Rumah (BDR) dengan peserta didik. Hal ini dialami merata oleh seluruh pendidik dari jenjang prasekolah hingga ke tingkat perguruan tinggi sesuai dengan Surat Edaran Mendikbud Nomor 4 Tahun 2020 yang diperkuat dengan SE Sesjen Nomor 15 Tahun 2020 tentang
Pedoman Pelaksanaan BDR selama pandemi Covid19.

Perubahan proses belajar mengajar dalam pembelajaran jarak jauh ini dilakukan untuk mendukung program pemerintah menekan penyebaran Covid-19. Keadaan ini menuntut sekolah dan guru untuk melakukan peningkatan kualitas dan layanan untuk tetap dapat melaksanakan proses belajar mengajar meskipun dilaksanakan secara daring/online. Masa pandemi ini memberi tantangan baru bagi pendidik dalam menggunakan keahlian dan kreativitas untuk 
menciptakan pembelajaran yang efektif selama Pembelajaran Jarak Jauh berlangsung. Guru dituntut untuk mengembangkan pengetahuan, keterampilan, kreativitas dan juga kepercayaan diri saat melakukan pembelajaran secara daring/online kepada peserta didik (Prima, E \& Lestari, 2021).

Oleh karena itu dibutuhkan penyesuaian dalam desain pembelajaran sehingga proses belajar mengajar tetap berjalan dengan baik meskipun dilaksanakan secara daring/online. Panduan Kemendikbud (Pusdatin, 2020), menyebutkan peran guru yang harus menyiapkan sarana teknologi dan jika perlu, mengikuti pelatihan ekstra untuk pengajaran jarak jauh, serta media dan sumber belajar daring sesuai dengan target kurikulumnya. Namun, agar terlaksana sesuai dengan yang diharapkan terdapat masalah seperti yang dikemukakan oleh (Harahap \& Purwanta, 2021) menyatakan bahwa problematika yang muncul dalam pembelajaran daring/online adalah dari segi media pembelajaran, yaitu kurangnya pemahaman guru dalam menggunakan aplikasi pembelajaran dan pembuatan media pembelajaran. Padahal idealnya media pembelajaran dapat menjadi alat untuk membantu proses belajar mengajar sehingga makna pesan yang disampaikan menjadi lebih jelas dan tujuan pendidikan atau pembelajaran dapat tercapai dengan efektif dan efisien (Ikhsan et al., 2021).

Media yang dapat di gunakan dalam daring/online bagi anak usia dini adalah video pembelajaran. Video pembelajaran dapat dijadikan media pembelajaran yang efektif bagi anak usia dini ((Dewi \& Rimpiati, 2016). Media pembelajaran yang diberikan kepada anak usia dini juga memiliki peran yang sangat baik untuk memotivasi dan merangsang anak dalam bereksperimen dan bereksprolasi (Mahyudin, 2020). Senada dengan hal ini (Asyhar, 2011) menyatakan bahwa media mampu membuat pembelajaran lebih menarik (Joyfull learning), bahkan pesan dan informasi menjadi lebih jelas dan mampu menghadirkan objek yang sulit dijangkau oleh peserta didik dalam hal ini anak usia dini. Selain itu, media yang dipergunakan pada anak usia dini memiliki tujuan untuk mengembangkan kemampuan kognitif dengan memberikan rangsangan berupa gambar bergerak dan suara, serta menyampaikan pesan untuk mempengaruhi sikap dan emosi (Fitria, 2014).

Namun dalam penggunaan video pembelajaran terdapat kendala yang dihadapi yaitu pada fase pembuatan. Kemampuan guru dan belum terbiasanya menggunakan teknologi digital menjadi hambatan dalam penggunaannya (Kurniawaty et al., 2021). Selain itu dibutuhkan sarana prasarana yang mumpuni dan kemampuan hardskill dalam membuat video pembelajaran (Ardi et al., 2021).

Berdasarkan observasi dan wawancara Tim Prodi PG-PAUD bersama Kepala Sekolah, TK Negeri Kintamani memerlukan pendampingan guna meningkatkan mutu pendidikan dalam kegiatan belajar dari rumah. Bentuk pendampingan yang diperlukan yaitu pembuatan video pembelajaran (dari proses pengambilan gambar, editing, hingga unggah di kanal youtube). Adapun tujuan pendampingan ini adalah melatih dan mendampingi guru dalam pembuatan video pembelajaran (dari proses pengambilan gambar, editing, hingga unggah di kanal youtube). Pendampingan diperlukan guna meningkatkan pengetahuan dan wawasan tenaga pendidik dan kependidikan di TK Negeri Kintamani.

\section{METODE}

Metode penyampaian dalam kegiatan PKM ini dilakukan melalui presentasi dan praktik langsung. Adapun pelaksanaan aktivitas program pengabdian prodi dilakukan dengan tahap-tahap sebagai berikut: 1) Sosialisasi pelaksanaan program pada mitra, yakni TK Negeri Kintamani; 2) kegiatan pengenalan konsep media video pembelajaran; 3) kegiatan pengenalan aplikasi media video; 4) kegiatan pelatihan pengambilan gambar video pembelajaran; 5) Pelatihan mengedit video pembelajaran yang dibuat dengan menggunakan aplikasi; 6) Pelatihan menggunggah video pembelajaran di kanal youtube sekolah; dan 7) Monitoring dan evaluasi hasil pelatihan pembuatan video pembelajaran bagi anak usia dini. Evaluasi terhadap keseluruhan kegiatan pengabdian kepada masyarakat yang dilakukan mencakup seluruh proses kerja dari awal sampai 
berakhirnya pelatihan menggunakan indikator capaian.

\section{HASIL DAN PEMBAHASAN}

Kegiatan PKM Prodi ini dilaksanakan di Jalan Raya Kintamani, Desa Kintamani Kecamatan Kintamani Kabupaten Bangli, Provinsi Bali. Berikut ini gambaran lokasi program pengabdian masyarakat prodi.

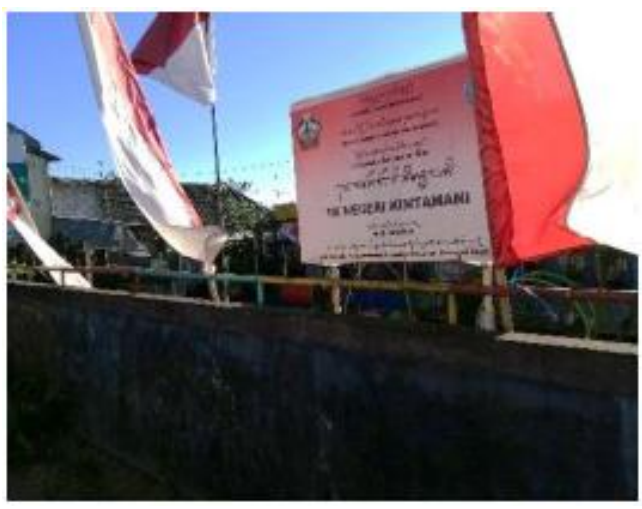

Gambar 1. TK Negeri Kintamani

Kegiatan pelatihan dilaksanakan di TK Negeri Kintamani. Peserta yang terlibat berjumlah 9 guru. Kegiatan dilaksanakan sebanyak 4 kali pertemuan yaitu pada bulan November dan Desember 2020. Pelaksanaan berlangsung dari pukul 09.00 s.d selesai dengan tetap memperhatikan protokol kesehatan.

Pelaksanaan pengabdian masyarakat ini terdiri dari beberapa tahap, yaitu ceramah, tanya jawab, praktik pembuatan video, praktik mengedit video menggunakan aplikasi, dan praktik mengunggah video di kanal youtube sekolah. Ceramah digunakan untuk menyampaikan pengetahuan, manfaat, dan tujuan secara umum pembuatan video pembelajaran sebagai media belajar selama pembelajaran online/daring berlangsung. Proses pelatihan dan pendampingan dilakukan secara langsung di sekolah untuk memudahkan penyampaian materi serta teknis membuat video dan mengedit video.

\section{Pengenalan Media Video Pembelajaran}

Kegiatan pertama yang dilakukan adalah ceramah dengan memberikan materi pengenalan media video pembelajaran bagi anak usia dini.

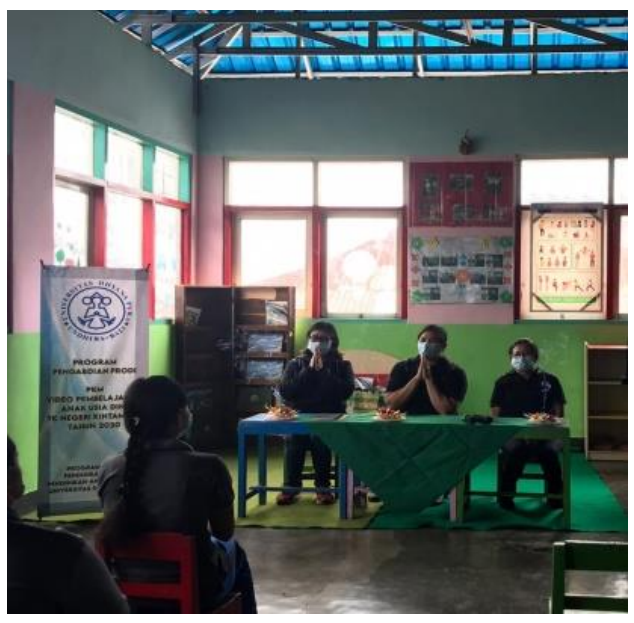

Gambar 2. Pembukaan Kegiatan PKM

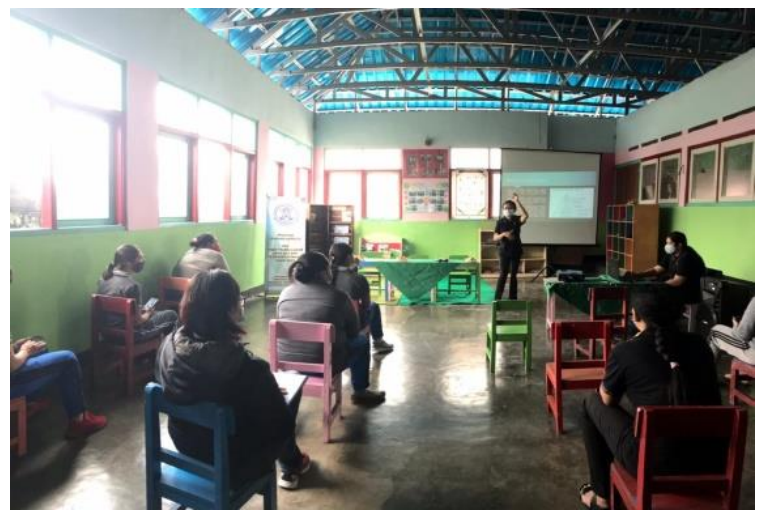

Gambar 3. Materi konsep media video pembelajaran

Peserta pelatihan yaitu guru-guru nampak sangat antusias memperhatikan pemaparan materi beserta contoh-contoh yang disajikan dan memberikan respon positif karena peserta baru pertama kali mendapat kegiatan pelatihan pembuatan video pembelajaran.

\section{Pelatihan Pembuatan Video Pembelajaran}

Setelah peserta pelatihan menerima pengenalan materi media video pembelajaran, peserta mendapatkan pelatihan tentang pembuatan 
media video. Peserta pelatihan dibagi kedalam 2 kelompok agar lebih mengerti proses dalam pembuatan video.
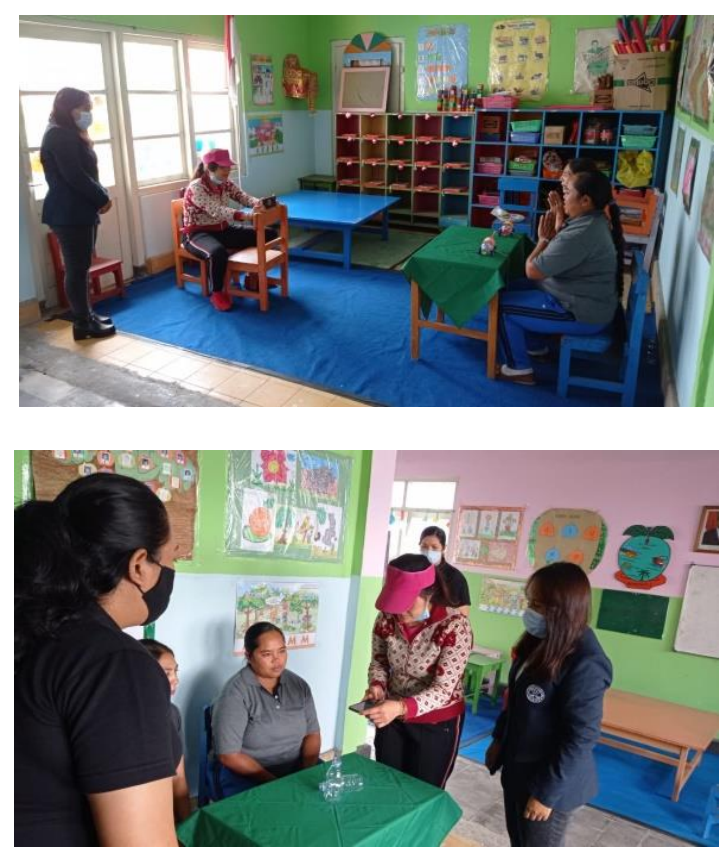

Gambar 4. Kelompok 1
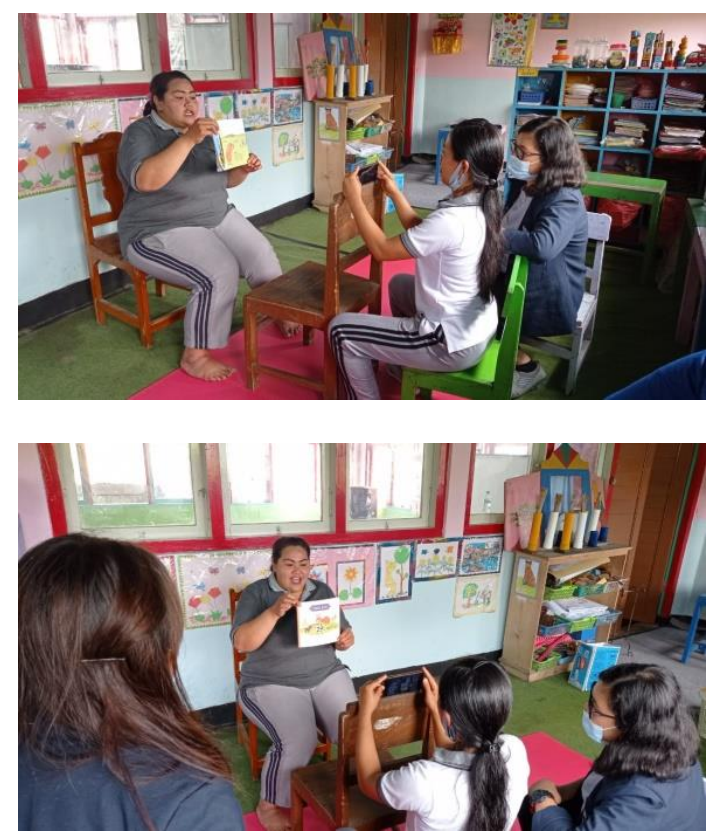

Gambar 5. Kelompok 2
Dalam pembuatan video kelompok sebagian peserta ada yang membawakan materi yang akan dibuatkan video dan ada peserta yang akan mengambil video pembelajaran. Peserta pada pembuatan video menggunakan perangkat pribadi berupa smartphone.

\section{Pendampingan Proses Editing Video Pembelajaran}

Kegiatan selanjutnya yaitu peserta melaksanakan praktik editing menggunakan aplikasi Inshot. Aplikasi Inshot dipilih karena memiliki fitur yang mudah digunakan oleh peserta yang baru pertama kali hendak melakukan proses editing.
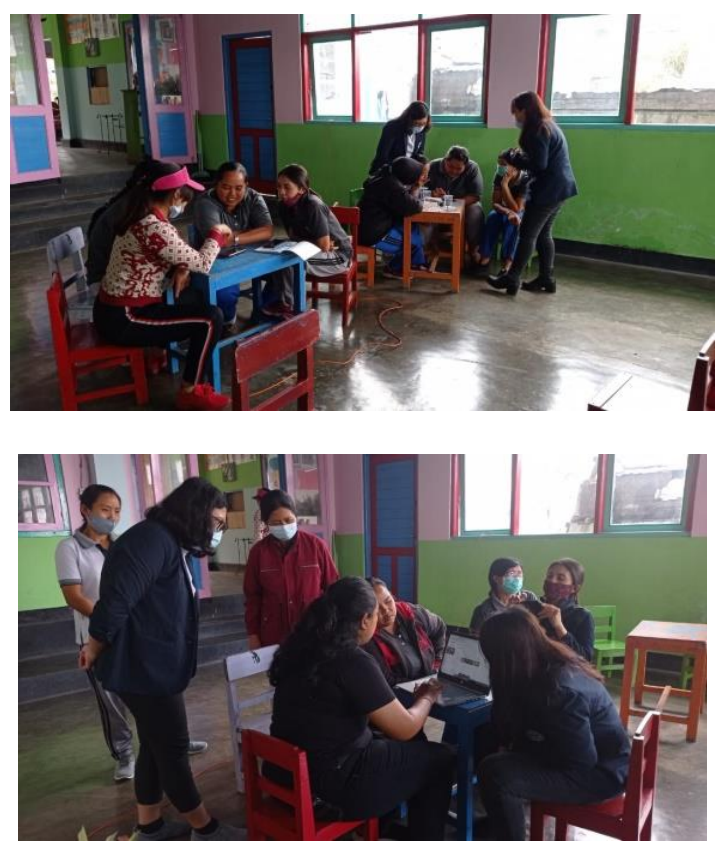

Gambar 6. Pendampingan dalam proses editing

Selain dari Tim PKM Prodi, peserta pelatihan juga mendapatkan bimbingan dari mahasiswa PG-PAUD Universitas Dhyana Pura. Pendampingan ini bertujuan agar peserta mampu merancang media video yang sesuai bagi anak usia dini. 


\section{Monitoring dan Evaluasi}

Kegiatan monitoring dan evaluasi dilaksanakan untuk mengetahui perkembangan pembuatan video oleh peserta pelatihan. Dalam kegiatan monitoring dan evaluasi yang sudah dilakukan di TK Negeri Kintamani, peserta mengunggah video pembelajaran yang telah dipersiapkan pada kanal youtube sekolah. Hasil yang didapat dari kegiatan monitoring dan evaluasi ini adalah video pembelajaran yang telah diunggah di youtube.

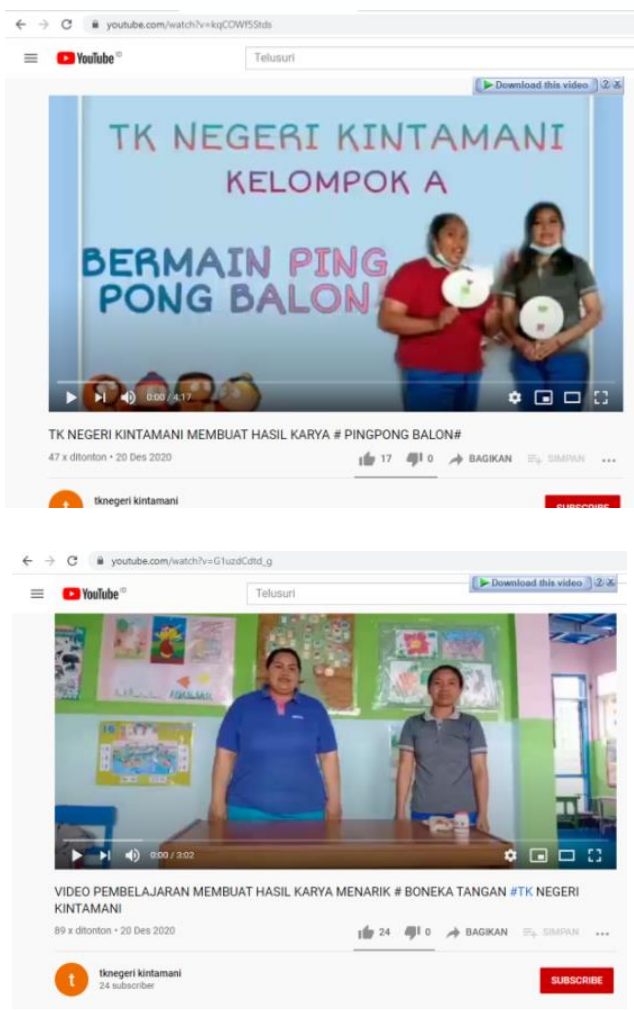

Gambar 7. Kanal Youtube TK Negeri Kintamani

Selain itu peserta menyatakan bahwa manfaat yang diperoleh peserta dan lembaga sangat tinggi dalam pelatihan dan pendampingan yang dilakukan. Para peserta banyak yang menyampaikan kepuasannya terhadap kegiatan yang diikuti dan menghendaki kegiatan ini dilanjutkan kembali dengan durasi yang lebih panjang dan materi yang bertambah.

\section{SIMPULAN}

Pelaksanaan PKM Prodi di Jalan Raya Kintamani, Desa Kintamani Kecamatan Kintamani Kabupaten Bangli, Provinsi Bali dengan mitra yaitu TK Negeri Kintamani telah berjalan sesuai rencana dengan tujuan awal yaitu peserta pelatihan dipersiapkan untuk mampu membuat video pembelajaran anak usia dini, meskipun belum semua peserta pelatihan menguasai dengan baik materi yang disampaikan. Kegiatan ini mendapat sambutan sangat baik terbukti dengan keaktifan peserta mengikuti pelatihan dengan tidak meninggalkan tempat sebelum waktu pelatihan berakhir.

Kegiatan ini mendapat respon positif dari guru-guru mitra serta memberikan dampak positif bagi mitra. Kepala sekolah juga sangat mendukung kegiatan PKM Prodi ini karena merasa sangat terbantu untuk menambah pengetahuan guru-guru sehingga dapat memperbaiki kualitas pembelajaran yang dilakukan secara online. Luaran yang dihasilkan adalah video pembelajaran yang telah diunggah di kanal youtube TK Negeri Kintamani. Dari kegiatan monitoring dapat disimpulkan telah mencapai target, dimana guru mampu mengambil gambar untuk pembuatan video, mengedit video, dan memasukkannya ke youtube TK Negeri Kintamani.

\section{UCAPAN TERIMA KASIH}

Tim Pengabdian Kepada Masyarakat dari Program Studi Pendidikan Guru-Pendidikan Anak Usia Dini mengucapkan terima kasih kepada berbagai pihak yang telah mendukung kelancaran pelaksanaan pengabdian ini, antara lain: 1) Rektor Universitas Dhyana Pura; 2) Ketua dan staf LPPM yang telah memfasilitasi PKM Prodi ini; 3) Ketua Program Studi PG-PAUD serta 4) TK Negeri Kintamani, Bangli yang telah memberikan kesempatan untuk melaksanakan PKM.

\section{REFERENSI}

Ardi, R. F. P., Purmadi, A., Wibawa, R., Maulachela, A. B., Juliansyah, A., \& Kumoro, D. T. (2021). Pemanfaatan Aplikasi VN Untuk Pembuatan Video Pembelajaran Menggunakan 
Telepon Pintar Kepada Guru PAUD/TK Gugus 3 Kota Mataram. Bakti Sekawan, 1(1), $25-28$.

Asyhar, Rayandra. (2011). Kreatif Mengembangkan Media Pembelajaran. Persada Press.

Dewi, L. M. I., \& Rimpiati, N. L. (2016). EFEKTIVITAS PENGGUNAAN MEDIA PEMBELAJARAN VIDEO INTERAKTIF DENGAN SETING DISKUSI KELOMPOK KECIL UNTUK MENINGKATKAN KETERAMPILAN BERPIKIR KRITIS PADA ANAK USIA DINI. Jepun: Jurnal Pendidikan Universitas Dhyana Pura, 1(1), 31-46.

Fitria, A. (2014). PENGGUNAAN MEDIA AUDIO VISUAL DALAM PEMBELAJARAN ANAK USIA DINI. Cakrawala Dini, 5(2), 57-62.

Harahap, D., \& Purwanta, E. (2021). Problematika Pembelajaran Daring dan Luring Anak Usia Dini bagi Guru dan Orang tua di Masa Pandemi Covid 19. Obsesi, 5(2), 1823-1836.

Ikhsan, A. N., Hidayat, M., \& Suhaman, J. (2021). PELATIHAN PEMBUATAN VIDEO PEMBELAJARAN DENGAN MENGGUNAKAN POWERPOINT DI MI
MUHAMMADIYAH

WANGON.

SELAPARANG, 4(3), 517-520.

Kurniawaty, L., Ristiani, I., Apriliani, S. R. A., Gustini, Sa'diyah, H. M., \& Rosdiana, D. (2021). PENGGUNAAN VIDEo PEMBELAJARAN BAGI ANAK USIA DINI DALAM PEMBELAJARAN DARING. JURNAL PENGABDIAN KEPADA MASYARAKAT.

Mahyudin. (2020). Peran Media Pembelajaran Guru Pendidikan Anak Usia Dini (PAUD) di Provinsi Jambi. Jurnal Ilmiah Universitas Batanghari Jambi, 20(1), 60-67.

Prima, E \& Lestari, P. I. (2021). PEMBELAJARAN SAINS BAGI ANAK USIA DINI MELALUI PEMBELAJARAN BERBASIS PROYEK PADA MASA BELAJAR DARI RUMAH. Media Edukasi: Jurnal Ilmu Pendidikan, 5(1), 1-8.

Pusdatin, K. (2020). Panduan Pembelajaran Jarak Jauh. 